\title{
MTHFR Gene Polymorphism In Patients Of Myocardial
}

\section{Infarction}

\section{V.Venkatesh', V.Sathish Kumar ${ }^{2}$, J.Vijaya Lakshmi ${ }^{3}$, Dr.SK.Abdul Rahaman ${ }^{4}$ \\ ${ }^{1}$ M.SC, Aurobindo Pharma Ltd, Vizianagaram, Andhrapradesh, India. \\ ${ }^{2}$ Pharm.D, Nirmala College Of Pharmacy, Guntur, Andhrapradesh, India. \\ ${ }^{3}$ Sr.Scientist, Translational Research Institute Of Molecular Sciences, Visakhapatnam, Andhrapradesh, India. \\ ${ }^{4}$ Professor, Nirmala College Of Pharmacy, Guntur, Andhrapradesh. India.}

\section{ABSTRACT :}

Homocysteine is an emerging new risk factor for cardiovascular disease. A common polymorphism in the gene coding for the 5,10-methylenetetrahydrofolate reductase (MTHFR) is associated with a decreased activity of the enzyme due to thermolability. There is an accumulating evidence that adequate intake of folate may protect the risk of developing the athero-thrombotic disease and its complications. Hyperhomocysteinemia (HCA)either due to mutation of MTHFR gene or deficiency of vitamin B12 and folic acid, has been reported as a risk factor for coronary artery disease (CAD).the present study was aimed to determine plasma homocysteine (hcy) levels and to evaluate MTHFR C677T gene polymorphism as risk factors for CAD in younger Indians. the effect of vitamin B12 and folic acid supplements on the raised plasma hcy levels in patients with CAD was also assessed. In our results, 6 cases are effected with a mutation in MTHFR gene. among them 4 individuals may face the future threat of myocardial infarction remaining 2 individuals are mutated and risk factors are similar to that of myocardial infarction.

Keywords: myocardial infarction, MTHFR, cardiovascular disease, folic acid.

Corresponding Author: V.Venkatesh,

Aurobindo Pharma Ltd,

Vizianagaram, +919951364135,

Email: venki.msc13@gmail.com

\section{INTRODUCTION:}

A myocardial infarction(MI) is defined as obstruction of blood flow in a coronary artery resulting in cell death of myocardial tissues or myocytes. Obstruction of blood flow may cause by 'ATHEROSCLEROSIS' '-5.

$>$ MI may cause by homocysteine associated with coronary artery diseases.

$>$ Homocysteine may develop the cardiovascular disease. 
Homocysteine causes damage to the lining of blood vessels increases clot formation \& indicator of cardiovascular diseases.

Classical symptoms of acute myocardial infarction include sudden chest pain, shortness of breath, nausea, vomiting, palpitation, sweating, and anxiety women may experience fewer typical symptoms than men may shortness of breath a feeling of indigestion.

A high level of blood serum homocysteine (homocysteinemia) is a powerful risk factor for cardiovascular disease. Hyperhomocysteinemia (HCA)either due to mutation of MTHFR gene or deficiency of vitamin B12 and folic acid, has been reported as a risk factor for coronary artery disease. the present study was aimed to determine plasma homocysteine (hcy) levels and to evaluate MTHFR C677T gene polymorphism as risk factors for CAD, and to study the role of hcy in conjunction with a few other risk factors for CAD in younger Indians .the effect of vitamin B12 and folic acid supplements on the raised plasma hcy levels in patients with CAD was also assessed ${ }^{6-8}$. CAD due to atherosclerosis is associated with increased mortality and morbidity. various risk factors have been found to be associated with the development of CAD. the role of diabetes mellitus, smoking, and hyperlipidemia as risk factors for CAD is well-established. hyperhomocysteinemia (HCA) Known to be associated with increased thrombotic tendency has been considered as a risk for coronary artery disease and atherosclerosis whereas others have found no association between acute myocardial infarction and HCA. mild to moderate $\mathrm{HCA}$ is known to be due to genetic factors like a mutation in methylene tetrahydrofolate reductase genes or due to environmental factors like deficiency of vitamin B12 or folic acid. Mutations in the MTHFR gene could be one of the factors leading to increased risk of developing schizophrenia. schizophrenic patients having the risk allele (T/T) show more deficiencies in executive function tasks ${ }^{12-15}$.

\section{Mthfr Gene Polymorphism :}

\section{C677T SNP (Ala 222val):}

The MTHFR nucleotide at position 677in the gene has two possibilities: $\mathrm{C}$ (Cysteine) or $\mathrm{T}$ (thymine). $\mathrm{C}$ at position 677 (leading to an alanine at amino acid 222) is the normal allele. the 677T allele (leading to a valine substitution at amino acid 222) encodes a thermolabile enzyme with reduced activity ${ }^{16-18}$. The degree of enzyme thermolability assessed as a residual activity after heat inactivation ) is much greater in 677TT individuals (18-22\%) compared with $677 \mathrm{CT}(56 \%)$ and $677 \mathrm{CC}(66-67 \%)$. individuals of $677 \mathrm{TT}$ are predisposed to mild hyperhomocysteinemia (high blood homocysteine levels) because they have less active MTHFR available to produce 5-methyltetrahydrofolate (which is used to decrease homocysteine) low dietary intake of the vitamin folic acid can also cause mild hyperhomocysteinemia ${ }^{19-24}$.

\section{METHODS AND MATERIALS :}

Simple collection :

The present study includes six patients with myocardial infarction and five healthy individuals as controls to analyse the mutation status in MTHFR gene at codon 677(c $\geq$ T) that resulted in the 
substitution of alanine by valine by PCR -RFLP analysis by using H1NF-1restriction enzyme which will yield 198bp for alanine variant and $175 \mathrm{bp}+23 \mathrm{bp}$ for valine variant. on gel electrophoresis, the 23bp band cannot be visualized while 198bp and 175bp bands can be visualized .peripheral blood $(2 \mathrm{ml})$ samples were collected from the above patients and control groups with prior consent. samples were collected into sterile tubes containing EDTA. samples were stored at $-20^{\circ} \mathrm{c}$ till DNA isolation.

DNA isolation:

D DNA was isolated by simple, rapid, non-enzymatic method (Lahiri and Nurnberger,1991).for all solutions use double distilled water, autoclaved. All solutions should be filtered and autoclaved except $\mathrm{NaCl}$ and SDS.

Procedure:

$>$ To $2 \mathrm{ml}$ of blood add equal volume of TKMI buffer and add 2-3 drops of Triton 100(RBSlyses)

$>$ Vortex well and spin at $2700 \mathrm{rpm}$ for 10minutes. Discard the supernatant to the pellet adds an equal amount of TKMI buffer and spin at $2700 \mathrm{rpm}$ for 10 minutes.

$>$ Discard supernatant and repeat the wash with TKMI buffer until white pellet is obtained.

$>$ To the white pellet add $80 \mu 1$ of TKM2 buffer and $12.5 \mu$ l of $10 \%$ SDS (WBC lysis )and vortex well and incubate in a water bath for 15 minutes at $55^{\circ} \mathrm{c}$. After the pellet is dissolved add freshly prepared $35 \mu \mathrm{l}$ of $\mathrm{NaCl}$ (to remove contaminants ).

$>$ Vortex well and incubate for 10 minutes at $55^{\circ} \mathrm{c}$ in a water bath.Centrifuge at 1200rpm for 5 minutes. The supernatant is collected in a fresh vial and add double the amount of $100 \%$ ethanol.

$>$ Vortex the tube until the DNA is precipitated.Centrifuge at 1200rpm for 3minutes.

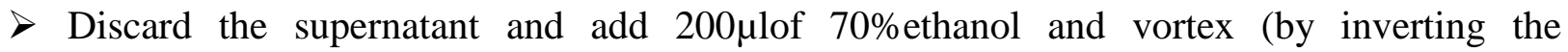
tube)thoroughly and spin for 2 minutes.Discard the supernatant and dry the pellet.

$>$ After the DNA is dried add $100 \mu 1$ of TE buffer and dissolve at $65^{\circ} \mathrm{C}$

$>$ Store the DNA solution at $-20^{\circ} \mathrm{c}$.

DNA analysis :

Genomic DNA obtained from patients with MI was analyzed to determine the distribution of $677 \geq$ T mutation in MTHFR gene using PCR-RLFP.

The polymorphic locus was studied were genotyped by amplifying genomic DNA in 40cycles, three-step PCR appropriate annealing temperature and additives were optimized for the system.

Quantity assessment :

Prior to analysis, DNA sample should be quantitated and checked for purity and integrity.based on its structure DNA absorbs light in the ultraviolet range, specifically at a wavelength of $260 \mathrm{~nm}$.

A volume of 1 at OD $260 \mathrm{~nm}$ is equal to $50 \mathrm{ng} / \mu \mathrm{l}$ double-stranded DNA.

Therefore, to calculate the concentration of DNA the following formula can be used.

Concentration of DNA $=260$ abs $\times 50 \times$ dilution factor(at the time of OD taken

(OD at $260 \mathrm{~nm} \times 50 \times 100)$. 
PCR-RFLP(Restriction fragment length polymorphism - polymerase chain reaction ):

PCR can be applied only when the nucleotide sequence of at least one short DNA segment on each side of the region of interest is known. the procedure of PCR technique involves using synthetic oligonucleotides (amplimers, primers) complementary to this known sequence of prime enzymatic amplification of the target DNA.

The method by which PCR works:

$>$ Two small fragments of DNA -20bp long called oligonucleotide primers are synthesized

$>$ These primers are complementary images to each end of the DNA sequence of interest.

$>$ The reaction contains the source DNA, the primers, the four deoxynucleotide triphosphates$\mathrm{d}$ ATP, d CTP, d GTP, d TTP, thermal stable DNA polymerase and its reaction buffer, the most critical component of which is $\mathrm{Mg}+2$.

The reaction involves 3 stages carried out at different temperatures:

$>$ Denaturation of the double-stranded DNA at $94^{\circ} \mathrm{c}$ for human genomic DNA the thermal energy at $94^{\circ} \mathrm{c}$ is sufficient to overcome the hydrogen bonding between the base pairs of the two DNA strands.

$>$ Annealing of primers to the resulting single-stranded templates carried out at $=55^{\circ} \mathrm{c}$, the optimal temperature depending upon the primer sequence the primers bind specifically to complementary DNA sequence present on the denatured genomic DNA which serves as the template. The 3'end of both the primers face each other and they provide the free 3 ' $-\mathrm{OH}$ required for the covalent extension.

$>$ DNA synthesis: primer extension is generally carried out at $72^{\circ} \mathrm{c}$ DNA polymerase replicates the DNA segment between the sites complementary to the oligonucleotide primers. The synthesis occurs at the rate 20 nucleotide /sec.

$>$ Each group of three reactions is termed as PCR cycle and theoretically doubles the amount of the original target sequence.

$>$ Amplification is exponential $(2,4,8,16,32, .$.$) .the products of the first cycle of replication are$ then denatured, annealed to primers and replicated again..the PCR is a chain reaction because newly synthesized in subsequent cycles.these cycles are repeated 25-35 times resulting in the synthesis of millions of copies of the amplified DNA fragment .each round of amplification takes about 5-10mins .at the end of Apcr, a sample of the reaction mixture is usually analyzed by agarose gel electrophoresis.

$>$ Initially, PCR was performed with DNA polymerase -I of E.coli as the replicate because this enzyme is heat activated during the denaturation step, new enzyme had to be added at each cycle. Later a heat stable DNA polymerase was discovered in the thermophilic bacterium - thermos aquatics, which is called Taq polymerase (T-aquaticus polymerase ). This microorganism which was found in the hot springs of the yellow store national park, thrive at $75^{\circ} \mathrm{C}$ temperatures and have enzymes with maximum activity at High Temperature.Taq resist inactivation even at $94{ }^{\circ} \mathrm{c}$. 
PCR analysis:

The MTHFR gene was amplified by polymerase chain reaction in a $10 \mu \mathrm{mm}$ Tris $\mathrm{HCl}, 50 \mathrm{~mm}$ $\mathrm{KCl}, 0.2 \mathrm{~mm}$ of each d NTPs, 200p mol of each primer, an optimal concentration of $\mathrm{MgCl} 2$ $\& 0.5 \mathrm{U}$ of Taq DNA polymerase and 100ng of genomic DNA.

PCR protocol(Stoneking et al .1970)

Agarose gel electrophoresis :

After PCR, the samples were subjected to $2 \%$ agarose gel electrophoresis at $100 \mathrm{~V}$ for $20-30$ minutes. Ethidium bromide stained gels were visualized under UV light and were documented. band sizes were compared to molecular weight marker of 100-1000bp for confirmation. agarose gel showing the 198bp (alanine) and $175+23 \mathrm{bp}$ (valine) at codon $677(\mathrm{C}>\mathrm{T})$ mutation in MTHFR gene in myocardial infarction patients and control individuals.

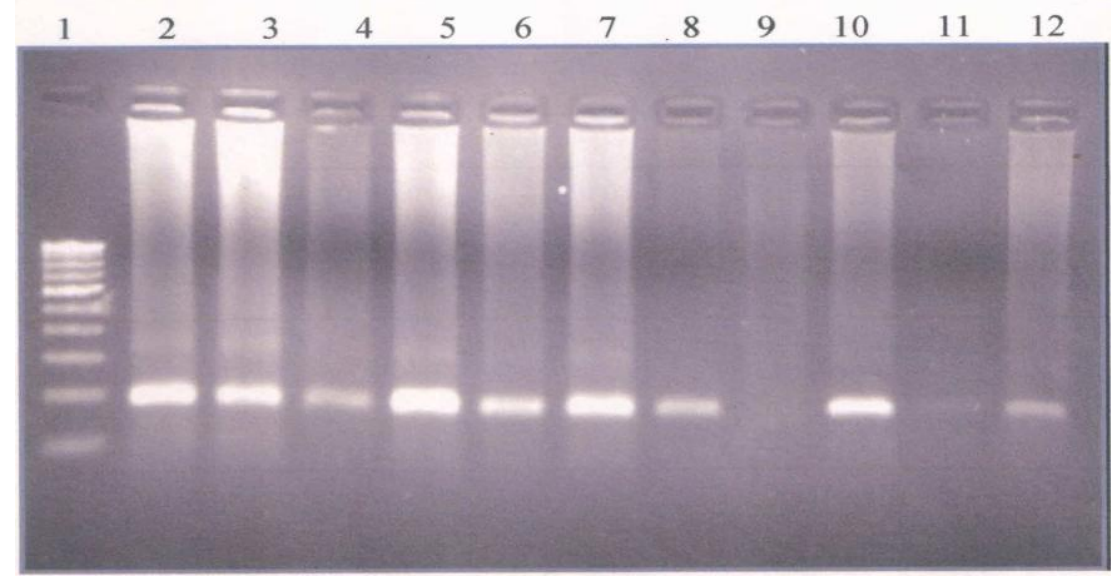

lane 2-7: MI patients; lane 8-12: control group.

lane 1: 100bp DNA ladder; lane 2,3,5,7,10: 198bp+175bp bands (val/ala heterozygotes)

lane 4,8,11: 198bp (valine homozygotes); lanes 6,8,12: 175bp (alanine homozygotes)

Quality check of genomic DNA by agarose gel electrophoresis

\section{RESULTS AND DISCUSSION:}

A significant difference $(\mathrm{p} \leq 0.001)$ was found between mean fasting levels of plasma hcy in cases $(22.14+/-10.62 \mu \mathrm{mol} / \mathrm{liter})$ and controls $(17.38+/-\mu \mathrm{mol} / \mathrm{l})$ with an odds ratio as $1.93(95 \%$ $\mathrm{Cl}, 1.27-2.94)$. levels of cholesterol, $\mathrm{LDL}$ and triglycerides were significantly $(\mathrm{P} \leq 0.001)$ higher in cases compound with controls. Our study showed a significant correlation between hyperhomocysteinemia and coronary artery disease. Multivariate analysis by logistic regression of the various risk factors of a CAD when all other factors were controlled. significant posttreatment decrease found in their CT or TT genotype of C677T MTHFR gene. further studies to look at the plasma levels of folate and cobalamin and their associated with hcy are required to be done. In an attempt to understand the association of $677 \mathrm{C} \geq \mathrm{T}$ mutation with a myocardial infarction, genotyping of the polymorphic variants (alanine /valine) in MTHFR gene was carried out. MTHFR mutation (677C $\geq \mathrm{T}$ IN MTHFR gene was analyzed by PCR-RFLP in 6 MI patients and 5 healthy controls to determine the genotype. the genotype frequencies were identified as 
for the II genotype, $40 \%$ (4 cases) for the heterozygous ID genotype respectively. the genotype and percentage frequencies are given in table 1.

Table-1: Type frequencies of $677 \mathrm{C} \geq$ Tmutation at codon 226 of MTHFR gene in cases and controls and their association of risk of MI patients and controls.

\begin{tabular}{|c|c|c|c|}
\hline $\begin{array}{c}\text { MTHFR 677 } \geq \mathrm{T} \\
\text { genotype }\end{array}$ & Cases $(\mathrm{n}=6)$ & Controls $(\mathrm{n}=4)$ & $\mathrm{X}_{2} ; \mathrm{p}$ value \\
\hline CC & 0 & 3 & \\
\hline CT & 4 & 1 & $6.7: 0.03$ \\
\hline TT & 2 & 0 & \\
\hline
\end{tabular}

There is a significant difference between the distribution of $\mathrm{CC}$ (valine/alanine), CT (valine/alanine) and TT (alanine /alanine) genotypes in MI patients. table 2 shows the allele frequencies of $\mathrm{C} \& \mathrm{~T}$ in MTHFR gene in a myocardial infarction.

Table-2: Allele frequencies of valine (c) and alanine (T) at codon $226(677 \mathrm{C} \geq \mathrm{T})$ in MTHFR gene in MI patients and controls.

\begin{tabular}{|l|l|l|}
\hline & Cases $(\mathrm{n}=6)$ & Controls $(\mathrm{n}=4)$ \\
\hline C allele & 0.335 & 0.875 \\
\hline T allele & 0.665 & 0.125 \\
\hline
\end{tabular}

In this regard d taken to analyze the mutation of 6 cases and 4 controls, individual blood samples are MTHFR gene and risk factor of myocardial infarctions. The DNA was isolated from blood samples and checked the DNA for purity by spectroscopy method.

$>$ After that isolated DNA was subjected to DNA PCR method for amplification.

$>$ These DNA samples were digested with restriction endonucleases of H1NF-1 to get the mutated fragments in DNA samples of tests.

Finally, these samples will run in agarose gel electrophoresis for visualizing of digested or restricted fragments.

\section{CONCLUSION :}

In our results 6 cases are affected with a mutation in MTHFR gene among them 4 individuals may face the future threat of myocardial infraction remaining 2 individuals are mutated and risk factors are similar to that of myocardial infarction. the present study was carried out to evaluate plasma hcy levels and MTHFR C677T polymorphism as risk factors for CAD and to study the role of hcy in conjunction with a few other risk factors for CAD.

\section{REFERENCE :}

1) Mallinson T (2010).'myocardial infraction'. Focus on first aid (15):15. Retrieved 2010-6-8. 
2) Kosugi M, Kimura K, Ishikawa, et al.(March 2006). difference between men and women in terms of clinical features of ST-segment elevation acute myocardial infarction "circulation journal 70(3):222-226.DOI :10.1253/Cricj.70.222.PMID 165012583.Retrieved 2008-05-31.

3) Smith SC, Allen j, Blair SN, et al (may 2006)"AHA/ACC guidelines for secondary prevention for patients with atherosclerotic vascular disease:2006 update endorsed by the national heart, lung, and blood institute “ $\mathrm{j}$. am disease coll.cardiol.47(10):2130-9. DOI:10.1016/j.jacc. 2006. 04. 026. PMID 16697342.

4) Mustafic H, Jabre P, Caussin C, Murad MH, Escolano S, Tafflet M, Perrier MC, Marijion E, Vernerey D,Empana Jp, Jouven X. (2012 feb15)"main air pollutants and myocardial infarction : a systemic review and meta-analysis "JAMA:the journal of the American medical association 307(7):713-21.DOI:10.1001/JAMA.2012.126. PMID 22337682.

5) Yusuf S, Hawken S, Ounpuu S, Bautista L, Franzosi MG, Commerford P, Lang CC, Rumboldt Z, Onen CL, Lisheng L, Tanomsup S, Wangai P Jr, Razak F, Sharma Am, Anand SS, inter heart study investigations.(2005)."obesity and the risk of myocardial infarction in 21,000 participants from 52 countries :a case-control study"lancet 366(9497):1640-9.DOI :10.1016/S01040-6736(05) 67663-58.PMID 16271645.

6) Nyboe j, Jensen G, Appleyard M, Schnohr p.(1989)." risk factors for an acute myocardial infarction in Copenhagen.i.heriditary, educational and socioeconomic factors. copenhage city heart study “.eur heart j 10(10):910-6 PMID 2598948.

7) Clarke R, Halsey j, Bennett D, Lewington s. (February 2011).homocysteine and vascular disease: review of published results of the homocysteine-lowering trials. j.inherit.metab.dis .34(1):83-91.DOI:10.1007/510545-010-9235-Y.PMID 21069462.

8) Lonn e (September 2007). homocysteine in the prevention of ischemic heart disease, stroke, and venous thromboembolism: therapeutic target or just another distraction? curr.opin.hematol. 14(5):481-7.DOI:10.1097/moh .0b013E3282C48BD8.paid 17934354.

9) Wilson is, Ryan MC, Boyle AJ .(2006). the novel of $\mathrm{C}$ - reactive protein in cardiovascular disease: risk marker or pathogen. int $\mathrm{j}$ Cardiol 106(3):291-7DOI:10.1016/J.I card.2005.01.068. PMID 16337036.

10) Scannapieco FA, Bush RB, Paju s.(2003)"association between periodontal disease and risk for atherosclerosis, cardiovascular disease, and stroke. a systemic review "Ann Periodontol 8(10:38-53. DOI:10.1902/annals .2003.8.1.38 PMID 14971247.

11) D Aiuto F, Parker M, Nibali L, Suvan j, lessen j, Tonetti MS (2006). periodontal infectious cause changes in traditional and novel cardiovascular risk factors from a randomised controlled clinical trial. am heart j 151(5):977-84.DOI :10.1016/J.ahj.2005.06.018.PMID 16644317.

12) Födinger M, Hörl WH, Sunder-Plassmann G (2000). "Molecular biology of 5,10methylenetetrahydrofolate reductase". Journal of Nephrology. 13(1): 2033. PMID 10720211. 
DOI : https://dx.doi.org/10.26808/rs.ph.i7v6.01

International Journal of Pharmaceutical Science and Health

Issue 7, Vol.6 (November- December 2017)

Available online on http://www.rspublication.com/ijphc/index.html

ISSN $2249-5738$

13) Trimmer EE (2013). "Methylenetetrahydrofolate reductase: biochemical characterization and medical significance". Current Pharmaceutical Design. 19 (14): 2574-93. doi:

10.2174/1381612811319140008. PMID 23116396.

14) Tran P, Leclerc D, Chan M, Pai A, Hiou-Tim F, Wu Q, Goyette P, Artigas C, Milos R, Rozen R (Sep 2002). "Multiple transcription start sites and alternative splicing in the methylenetetrahydrofolate reductase gene result in two enzyme isoforms". Mammalian Genome. 13 (9): 483-92. doi:10.1007/s00335-002-2167-6. PMID 12370778.

15) Matthews RG, Daubner SC (1982). "Modulation of methylenetetrahydrofolate reductase activity by S-adenosylmethionine and by dihydrofolate and its polyglutamate analogues". Advances in Enzyme Regulation. 20: 123-31. doi:10.1016/0065-2571(82)900127. PMID 7051769.

16) Jencks DA, Mathews RG (Feb 1987). "Allosteric inhibition of methylenetetrahydrofolate reductase by adenosylmethionine. Effects of adenosylmethionine and NADPH on the equilibrium between active and inactive forms of the enzyme and on the kinetics of approach to equilibrium". The Journal of Biological Chemistry. 262 (6): 2485-93. PMID 3818603.

17) Yamada K, Strahler JR, Andrews PC, Matthews RG (Jul 2005). "Regulation of human methylenetetrahydrofolate reductase by phosphorylation". Proceedings of the National Academy of Sciences of the United States of America. 102 (30): 104549. doi:10.1073/pnas.0504786102. PMC 1180802 2. PMID 16024724.

18) Goyette P, Sumner JS, Milos R, Duncan AM, Rosenblatt DS, Matthews RG, Rozen R (Aug 1994). "Human methylenetetrahydrofolate reductase: isolation of cDNA mapping and mutation identification". Nature Genetics. 7 (4): 551. doi:10.1038/ng0894551a. PMID 7951330.

19) Sibani S, Christensen B, O'Ferrall E, Saadi I, Hiou-Tim F, Rosenblatt DS, Rozen R (2000). "Characterization of six novel mutations in the methylenetetrahydrofolate reductase (MTHFR) gene in patients with homocystinuria". Human Mutation. 15 (3): 2807. doi:10.1002/(SICI)1098-1004(200003)15:3280::AID-HUMU9>3.0.CO;2-

I. PMID 10679944.

20) Schneider JA, Rees DC, Liu YT, Clegg JB (May 1998). "Worldwide distribution of a common methylenetetrahydrofolate reductase mutation". American Journal of Human Genetics. 62 (5): 1258-60. doi: 10.1086/301836. PMC 1377093 б. PMID 9545406.

21) Frosst P, Blom HJ, Milos R, Goyette P, Sheppard CA, Matthews RG, Boers GJ, den Heijer M, Kluijtmans LA, van den Heuvel LP (May 1995). "A candidate genetic risk factor for vascular disease: a common mutation in methylenetetrahydrofolate reductase". Nature Genetics. 10 (1): 111-3. doi:10.1038/ng0595-111. PMID 7647779.

22) Reilly R, McNulty H, Pentieva K, Strain JJ, Ward M (Feb 2014). "MTHFR 677TT genotype and disease risk: is there a modulating role for B-vitamins?". The Proceedings of the Nutrition Society. 73 (1): 47-56. doi:10.1017/S0029665113003613. PMID 24131523.

23) Yamada K, Chen Z, Rozen R, Matthews RG (Dec 2001). "Effects of common polymorphisms on the properties of recombinant human methylenetetrahydrofolate 
reductase". Proceedings of the National Academy of Sciences of the United States of America. 98(26): 14853-8. doi:10.1073/pnas.261469998. PMC 64948 2. PMID 11742092.

24) Schwahn B, Rozen R (2001). "Polymorphisms in the methylenetetrahydrofolate reductase gene: clinical consequences". American Journal of Pharmacogenomics. 1 (3): 189201. doi:10.2165/00129785-200101030-00004. PMID 12083967.

25) Ojha RP, Gurney JG (Jan 2014). "Methylenetetrahydrofolate reductase C677T and overall survival in pediatric acute lymphoblastic leukemia: a systematic review". Leukemia \& Lymphoma. 55 (1): 67-73. doi:10.3109/10428194.2013.792336. PMID 23550988.

26) Bailey LB (Nov 2003). "Folate, methyl-related nutrients, alcohol, and the MTHFR 677C-->T polymorphism affects cancer risk: intake recommendations". The Journal of Nutrition. 133(11 Suppl 1): 3748S-3753S. PMID 14608109.

27) valensi P, Lorgis L, Cottin Y (march 2011)."prevalence, incidence,predictive factors and prognosis of silent myocardial infraction: a review of the lieterature. "arch cardiovasc Dis 104 (3):178-88.DOI:10.1016/j.acvd.2010.11.013.PMID 21497307.

28) Erhardt L, Herlitz j, Bossaert L, et al. (July 2002). "Task force on the management of chest pain “(pdf).Eur.heart. j.23(15):1153-76.DOI :1053/euhj.2002.3197.PMID 12206127.

29) Roe MT ,Messenger JC ,Weintraub WS, et al.(JULY 2010).Treatments ,trends , and outcomes of acute myocardila infraction and percutaneous coronary intervention. j.am.coll.cardiol. 56(4): 254-63.DOI:10.1016/J.JACC.2010.05.008.PMID 20633817.

30) O'Connor RE, Brady W, brooks SC, et al. (November 2010).part 10: acute coronary syndromes: 2010 American heart association guidelines for cardiopulmonary restriction and emergency cardiovascular care" circulation 122(18 suppl 3 3):s787 817. DOI:10.1161/CIRCULATIONAHA. 110.971028.PMID 20956226.

31) Van de Werf, Baxj, betriu A, et al.(December 2008).management of acute myocardial infarction in patients presenting with persistent ST-segment elevation: infraction of the European society of cardiology" Eur heart j.29(23):290945.DOI:10.1093/eurheartj/ehn416.PMID 19004841.

32) Hamm CW, Bassand jp, agewall S, et al. (December 2011)."ESC guidelines for the management of acute coronary syndromes in presenting without persistent ST-segment elevation: the task force for the management of acute coronary syndromes (ACS)in patients presenting without persistent ST -elevation of the European society of Cardiology(ESC). eur.heart j.32(23):2999-3054.DOI:10.1093/EURHEARTJ/Her 236. PMID 21873419.

33) Steptoe A, Kivimaki M (April2012)."stress and cardiovascular disease". NatRev Cardiol 9(6): 360-70.DOI :10.1038/nrcardio.2012.45. PMID 22473079.

34) Reznik AG (2010)."[Morphology of acute myocardial infarction at pre-necrotic stage]"(in Russian). Kardiogiia 50(1);4-8.PMID 20144151.

35) Moe KT , Wong p (march 2010).current trends in diagnostic biomarkers of acute coronary syndrome " $\{$.ann .acad.med. singap.39(3):210-5PMID 20372757.

36) Thygesen K, Alpert JS, white HD (October 2007)."universal definition of myocardial infarction"'eur .heart j.28(20):2525-38.DOI:10.109/eur Heart j/ehm 355.PMID 17951287. 
37) National Heart, lung and blood institute. heart attack warning signs. retrieved November 22, 2006.

38) Berger JP, Buclin T, Haller E, Van Melle G, Yersin B (March 190). right arm involvement and pain extension can help to differentiate coronary disease from chest pain of another origin: a prospective emergency ward study of 278 consecutive patients admitted for chest pain. j.intern.med.227(3):165-72.DOI:10:11111/J.1365-2796.1990.TB00138.X. PMID 2313224.

39) Little RA, Frayn KN, Randall PE, et al.(1986)." plasma catecholamines in the acute phase of the response to myocardial infarction "Arch Emerge med 3(1):20-7.PMC 1285314.PMID 3524599

40) Canto JG, Goldberg RJ, Hand MM, et al. (December 2007). symptom presentation of women with acute coronary syndrome: myth vs reality "Arch Intern.MED167(22):240513.DOI : 10. 1001/Archinte .167.22.2405. PMID 14597589.[DEAD LINK].

41) Mc Sweeney JC, Cody M, O'Sullivan p, Elberson k, Moser DK, Garvin BJ (2003).” women's early warning symptoms of acute myocardial infarction "circulation 108(21): 2619-23. DOI: 10:1161/01.CIR .0000097116.7C.PMID 14597589.

42) Kannel WB (1986). silent myocardial ischemia and infarction: insights from the Framingham study. Cardiol Clin 4(4):583-91.PMID 14597589.

43) Davis TM fortune P, Mulder J, Davis WA, Bruce DG (2004). silent myocardial infarction and its prognosis in a community -based cohort of type-2 diabetic patients: the Fremantle diabetes study. Diabetologia 47(3):395-9. DOI :10.1007/s00125-004-1344-4.pmid 14963648.

44) Acute coronary syndrome .american heart association .retried november 25,2006.

45) Wilson PW, D’Agostino RB, Levy D, Belanger AM, Silberschatz H, Kannel WB. (1998). prediction of coronary heart disease using risk factor categories (PDF).circulation 97(18):1837-47.DOI:10.1161/01.CIR .97.18.1837.PMID 9603539.

46) Saikku P, Leinonen M, Tenkanen L, Linnanmaki E, Ekman MR, Manninen V, manttariM, Frick MH, Huttunen JK.(1992).' chronic chlamydia pneumonia infection as a risk factor for coronary heart disease in the Helsinki heart study ".Ann inserts med 116(4):273-8.PMID 1733381.

47) Andrews R, Berger js, brown DL.(2005).'Effects of antibiotic therapy on outcomes of patients with coronary artery disease: a meta-analysis of randomized controlled trials".JAMA293 (21): 2641-7.DOI:10.1001/JAMA .293.21.PMID 15928286.

48) Muller JE, Stone PH, Turi ZG, et al.(1985)." circadian variation in the frequency of onset of acute myocardial infarction “.N.Engl.j.med.313(21):131522.DOI:10.1056/NEJM1213132103. PMID 2865677.

49) Beamer AD, Lee TH, Cook EF, et al. (1987)." diagnostic implications for myocardial ischemia of the circadian variation of the onset of chest pain”.Am.j.cardiol .60(13):9981002.DOI: 10.1016/0002-3149(87)903407. PMID 3673917.

50) Cannon CP, Mccabe CH, Stone PH, et al: Mccabe, stone, Schechtman, Thompson, Theroux, Gibson, Feldman, et al .(1997).' circadian variation in the onset of unstable angina and non- 
DOI : https://dx.doi.org/10.26808/rs.ph.i7v6.01

International Journal of Pharmaceutical Science and Health

Issue 7, Vol.6 (November- December 2017)

Available online on http://www.rspublication.com/ijphc/index.html

ISSN $2249-5738$

Q wave acute myocardial infarction (the TIMI III registry and TIMI IIIB)'Am.j.cardiol.79(3):253-8 DOI :10:1016/S0002-9149(97)00743-1.PMID 9036740.

51) Tofler GH, Brezinski D, Schafer Ai, et al .(1987)." concurrent morning increase in platelet aggregability and the risk of myocardial infarction and sudden cardiac death. N.engl.j.med. 316(24): 1514-8.DOI:10:1056/NEJMI 198706113162405.PMID 3587281. 